\title{
Lemiesz tłumacza. Tłumaczenie jako sposób wewnętrznej imigracji ${ }^{\text {}}$
}

\author{
ręka tłumacza: \\ Empedoklesowe współodczuwanie - \\ - Nihil humani a me alineum esse -: poezja ${ }^{2}$ \\ Paul Celan
}

Rodzice Amosa Oza w latach 30. ubiegłego wieku wyemigrowali z Ukrainy do Palestyny, a zatem pochodzili z tego samego chronotopu, co urodzony w 1920 r. w Czerniowcach Paul Celan. Oz przyszedł na świat w Jerozolimie w 1939 r. W autobiograficznej Opowieści o miłości i mroku tak wspominał rodziców:

[...] ojciec mój potrafił czytać w szesnastu czy siedemnastu językach (zawsze z rosyjskim akcentem). Matka mówiła czterema czy pięcioma językami, a czytała w siedmiu albo ośmiu. [...] Mnie uczyli wyłącznie hebrajskiego: być może z obawy, że znajomość języków obcych także ich syna wystawi na pokusy Europy, wspaniałej i zabójczej zarazem ${ }^{3}$.

Znajomość języków obcych wystawia także na pokusę przekładu, raz wspaniałego i zbawczego, raz zabójczego - dla tłumacza lub dla wiersza. Paul Celan należał do pokolenia rodziców Amosa Oza i było dla niego naturalne, że czyta w rozlicznych językach, choć podstawowa i niezbywalna stała się dla niego niemczyzna, z którą się zrósł i z której jako poeta nigdy nie zrezygnował. W pisanych po niemiecku wierszach znajdował językową sygnaturę dla Zagłady, w nich też starał się przywrócić językowi blask.

I Artykuł powstał w ramach projektu Miejsce i imię. Poeci niemieckojęzyczni pochodzenia żydowskiego, sfinansowanego ze środków Narodowego Centrum Nauki, przyznanych na podstawie decyzji numer DEC-2012/05/B/H52/04129.

${ }_{2}$ „Fremde Nähe”. Celan als Übersetzer: eine Ausstellung des Deutschen Literaturarchivs in Verbindung mit dem Präsidialdepartement der Stadt Züricb im Schiller-Nationalmuseum Marbach am Neckar und im Stadtbaus Zürich, Marbach am Neckar 1997, s. 375: „,eine Hand des Übersetzers: / Die Empedokleische Sympathie - / -Nihil humani a me alineum esse -: die Dichtung”. Tu i dalej - jeśli nie podano inaczej - tłum. J.R.

3 A. Oz, Opowieść o milości i mroku, thum. L. Kwiatkowski, Warszawa 2006, s. 6. 
Dla poetów wygnańców, poetów żydowskiego pochodzenia, posługujących się językiem niemieckim z dala od krajów niemieckojęzycznych, tłumaczenie poezji z niemieckiego lub na niemiecki było formą - jak ją nazwę - imigracji wewnętrznej, znamiennej dla „cudzoziemców”, którzy częściowy wewnętrzny azyl odnajdywali jako thumacze. Kontakt z „trudnym” językiem matki pozwalał im na przybliżanie się do bezpowrotnie utraconych: czasów, miejsc i osób.

Osiedlali się w wierszu, i pisanym, i czytanym, i przepisywanym z języka na język. Poeci emigranci z krajów niemieckojęzycznych, którzy nie przestali zamieszkiwać niemczyzny, wybierali różne drogi, by funkcjonować na jej obrzeżach Mascha Kaléko w USA, Nelly Sachs w Szwecji, Hilde Domin w Republice Dominikany, Celan we Francji, inni poeci czerniowieccy w światowej diasporze. Z jednej strony - zatrzymali dom w wydartym im języku dzieciństwa, ale z drugiej - odnajdowali oparcie w innym języku niż matczyny, żyli w codzienności obcego kodu. Na obczyźnie właśnie w profesji tłumacza odkryli zwornik, pozwalający scalić ich pękniętą tożsamość. Tłumaczenie okazało się sposobem oswajania własnego niezakorzenienia.

Ich niemczyzna została wytrącona z oków humanizmu przez Hitlera, Goebbelsa, Eichmanna. Ta niemczyzna, której musiał się nauczyć Włoch, Primo Levi, by mieć większe szanse na przeżycie (za obozowe lekcje niemieckiego płacił swoimi racjami chleba)4, zawisła nad przepaścią i drastycznie odsunęła się od niemczyzny oświeceniowych filozofów i romantycznych pisarzy.

George Steiner zauważa paradoksalną, nie do końca spełnioną $\mathrm{i}$ - jak twierdzi - niekiedy autodestrukcyjną koegzystencję Celana z językiem niemieckim. Dzięki własnym tłumaczeniom autor Róży niczyjej przesunął go na pozycję „zbawiennej obcości”:

Podchodził do niego z terapeutyczną beznamiętnością, widząc w nim tworzywo, na które był wprawdzie skazany, lecz które było jednocześnie [...] potencjalnie wrogie. [...] W tym procesie język docelowy zostaje wygnany i złamany. Popada $\mathrm{w}$ idiosynkrazje, które doprowadziły go niemal na skraj niekomunikatywności. Staje się językiem meta-niemieckim, oczyszczonym z historyczno-politycznego szlamu, dzięki czemu - i tylko dlatego - może się nim posłużyć głęboko żydowski głos po holocauścies.

4 P.S. Fiero, Schreiben gegen Schweigen: Grenzerfabrungen in Jean Amérys autobiograpbischen Werk, Hildesheim - Zürich - New York 1997, s. 97.

5 G. Steiner, Po wieży Babel. Problemy jezyyka i przekładu, tłum. O. i W. Kubińscy, Kraków 2000, s. 523-524. 
Powracając $\mathrm{w}$ powyższej analizie do problemu wrogości niemczyzny, Steiner interpretuje Celanowskie thumaczenia jako sposób destylacji języka. Przyjaciel autora Fugi śmierci i badacz jego twórczości, Peter Szondi, sięgał po słowa Waltera Benjamina $^{6}$ i notował, że Celan dokonuje w temacie oraz w stylu przekładanego utworu takiej zmiany, jaka w ramach tradycyjnej teorii przekładu byłaby wykroczeniem przeciw przykazaniu wierności.

Poezja, także ta przekładana, staje się dla Celana próbą określenia własnego miejsca, przy prawie niemożliwym wrośnięciu w nową przestrzeń. Shoshana Felman, może zbyt ostentacyjnie hipostazując język, takiej dopatrywała się motywacji zmagań poety z niemczyzną:

[...] by zgładzić w nim swoją własną zagładę, by na nowo zapanować nad mową, która naznaczyła jego własne wygnanie [...]. To gwałtowne i ekscytujące przedzieranie się przez mowę i pamięć odbywa się w ogniu walki, w języku i poezji, po to, by móc na nowo odziedziczyć język, z którego raz zostało się wydziedziczonym, by odebrać niemiecki nazistowskiej przeszłości, a mowę matki - jedyną własność wydziedziczonych - holocaustowi, za który ta mowa jest odpowiedzialna ${ }^{7}$.

Przyjaciółka pochodzącego z Czerniowców poety, Nelly Sachs, po ucieczce z Niemiec przekładała poezję szwedzką na niemiecki. W roku 1947 ukazała się zredagowana przez nią antologia Von Welle und Granit, w której posłowiu późniejsza noblistka pisała, że pierwsze $\mathrm{z}$ tych przekładów rodziły się $\mathrm{z}$ wdzięczności wobec Szwecji:

Różne kierunki stylów, które występują w tej małej rozpiętości pokoleniowej, udowadniają, że szwedzcy poeci poza szumem ich własnego morza dopuszczają do swoich uszu wiele podziemnych strumieni z całego świata i przez to nie pozostają w duchowej izolacji na własnej wyspie ${ }^{8}$.

${ }^{6}$ P. Szondi, Poetry of Constancy - Poetik der Beständigkeit. Celans Übersetzung von Shakespeares Sonett 105, w: Celan-Studien, Frankfurt am Main 1972, s. 18-19. Na temat Celanowskich przekładów zob. także: P. Gossens, Paul Celan Ungaretti-Übersetzungen, red., przyp. C. Winter, Heidelberg 2000; F. Pennone, Paul Celans Übersetzungspoetik. Entwicklungslinien in seinen Übertragungen französischer Lyrik, Tübingen 2007.

7 S. Felman, Nauczanie i kryzys albo meandry edukacji, thum. M. Lachman, „Literatura na Świecie” 2004, nr 1-2.

${ }^{8}$ Cyt. za: W.A. Berendsohn, Nelly Sacbs. Einfübrung in das Werk der Dichterin jüdischen Schicksals, Frankfurt am Main 1974, s. 106. 
O tej poezji dodawała: „transparentna jak przestrzeń, która ją obejmuje" 9 . Bliskie zapewne byłyby jej słowa nakreślone 27 września 1952 r. przez Celana w liście do wiedeńskiego poety i przyjaciela, Klausa Demusa: „Und Sprache ist innere Landschaft” - „Język jest wewnętrznym krajobrazem”.

\section{Wewnętrzny krajobraz niemczyzny - Mandelsztam Celana ${ }^{\text {II }}$}

Jürgen Lehmann biograficznie motywuje Celanowską praktykę przekładu, wskazując na Czerniowce jako miasto językowej polifonii ${ }^{\mathrm{I} 2}$. Poeta zaczął tłumaczyć jeszcze w młodości, między innymi krótkie opowiadania Franza Kafki, utwory Paula Eluarda oraz Antona Czechowa ${ }^{\mathrm{I}}$. Jego własna poetyka tłumaczenia literackiego rozwijała się w latach 60., gdy zaczął pracować jako lektor języka niemieckiego w École Normale Supérieure. Niekiedy thumaczył „dla chleba” (Brotübersetzungen), wszak niemałe honoraria otrzymywał choćby za przekłady Szekspira w NRD ${ }^{\text {I4 }}$. Inne $\mathrm{z}$ jego prac translatorskich motywowane były rodzinnym kontekstem, jak Notizen zur Malerei der Gegenwart Jeana Bazaine'a, związane z profesją żony ${ }^{15}$.

Twórca Meridianu przełożył Lebre vom Zerfall Emila Ciorana, sztukę Pabla Picassa, sonety Williama Szekspira, utwory Emily Dickinson, Marianne Moore, Roberta Frosta ${ }^{16}$, Johna Donne'a, Aleksandra Błoka, Siergieja Jesienina, Jewgenija Jewtuszenki, Wielmira Chlebnikowa, z włoskiego - Giuseppe Ungarettiego, z hebrajskiego - Davida Rokeaha, z portugalskiego - Fernanda

9 Ibidem, s. 107: „Transparent wie der Raum, der sie umgibt, steigt der Gedanke in sein Gleichnis gehüllt empor”.

ro P. Celan, K. i N. Demus, Briefwechsel. Mit einer Auswabl aus dem Briefwechsel zwischen Gisèle Celan-Lestrange und Klaus und Nani Demus, zebrał i przypisami opatrzył J. Seng, Frankfurt am Main 2009, s. 115. Dalej stosuję skrót CD i wskazuję numer strony, z której pochodzi cytat.

II Zob. też: A. Bonola, Osip Mandelstams „Egipetskaja marka”. Eine Rekonstruktion der Motivenmosaik, Munich 1995; C. Cavanagh, Osip Mandelstam and the Modernist Creation of Tradition, Princeton 1995; G. Freidin, A coat of many colors: Osip Mandelstam and bis mythologies of self-presentation, London 1987; A. Werberger, Paul Celan and Osip Mandelstam, „Arcadia” 1997, nr 32; U. Werner, Paul Celans geologische Lyrik, Munich 1998.

${ }_{12}$ Celan Handbuch, red. M. May, P. Goßens, J. Lehmann, Stuttgart - Weimar 2008, s. 180 .

I3 Ibidem, s. 184.

I4 Ibidem, s. 186.

15 Ibidem.

${ }^{16}$ Por. M. May, „Ein Klaffen, das mich sichtbar macht”. Untersuchungen zu Paul Celans Übersetzungen amerikanischer Lyrik, Heidelberg 2004. 
Pessoi $^{17}$. We wczesnych latach $\mathrm{w}$ Paryżu zajął się wierszami Golla i Apollinaire'a, pod koniec lat 50. pracował nad projektem stworzenia antologii francuskiej liryki (Antonin Artaud, Robert Desnos, Gérard de Nerval, Charles Baudelaire, Stéphane Mallarmé, Jules Supervielle; szczególne znaczenie miało dlań tłumaczenie Statku pijanego Arthura Rimbauda ${ }^{18}$.

Ze wspomnianym już Demusem korespondował także na temat swoich przekładów Szekspira, Błoka czy Rimbauda. O tym ostatnim pisał z Paryża 3 sierpnia 1957 r.: „Klausie, udało mi się, jak sądzę, coś znakomitego: thumaczenie Bateau Ivre. Dwa dziwne dni - trzeciego doszła jeszcze ostatnia zwrotka" (CD, s. 236) ${ }^{\mathrm{r} 9}$. Prosił przyjaciela o obiektywną ocenę pracy. Demus donosił z Wiednia 7 sierpnia 1957 r.: „Urodziłeś cud, i mówię to obiektywnie: cud. [...] Twoje tłumaczenie ma dystans; nie ulega czarowi tekstu i nie wyjaśnia" (CD, s. 239-240 $)^{20}$.

Najbardziej zażyła i wielopoziomowa jawi się relacja Celana z Mandelsztamem ${ }^{2 \mathrm{I}}$ : sam poeta - jak akcentuje John Felstiner uważał siebie za jego „sekretnego adresata” ${ }^{22}$. Nelly Sachs napisała w liście do autora Róży niczyjej o jego thumaczeniach poezji autora Kamienia: „Jak pan go wydobył z nocy z całym pejzażem jego języka, wilgotnym jeszcze i ociekającym źródłem [...]. Przejście na drugą stronę i $[. .$.$] nowy wiersz" { }^{23}$. Obrazy i słowne impulsy, które zaistniały $\mathrm{w}$ jego wyobraźni przy tłumaczeniu rosyjskiego poety, powrócą wszelako $\mathrm{w}$ jego własnych wierszach ${ }^{24}$. Celan w radiowej audycji o Mandelsztamie powiedział: „Wiersze to szkice do egzystencji: poeta życiem do nich mierzy” ${ }^{25}$. Spotykał

${ }^{17}$ Por. H. Pausch, Paul Celan, Berlin 1981, s. 29.

I8 Zob. U. Harbusch, Gegenübersetzungen. Paul Celans Übertragungen französischer Symbolisten, Göttingen 2005.

I9 „Klaus, mir ist, so glaube ich, ein «Wurf» geglückt: Die Übersetzung des Bateau Ivre. Zwei merkwürdige Tage warens - am dritten kam dann noch die letzte Strophe hinzu".

${ }^{20}$ „Ein Wunder hast Du geboren, und ich sage es objektiv: ein Wunder. [...] Das glücklichste Zeichen ist: Deine Übersetzung hat Distanz; bleibt nicht vom Text gebannt und erläutert nicht”.

${ }_{21}$ O. Mandelstamm, Gedichte. Deutsch von Paul Celan, Frankfurt am Main 1959; Dreirussische Dichter: Alexander Block, Ossip Mandelstamm, SergejJessenin. Gedichte übertragen von Paul Celan, Frankfurt am Main 1963.

${ }_{22}^{2}$ J. Felstiner, Paul Celan. Poeta, ocalony, Żyd, thum. M. i M. Tomalowie, Kraków - Budapeszt 2010, s. 180.

23 Por. P. Celan, N. Sachs, Briefwechsel, red. B. Wiedemann, Frankfurt am Main 1996.

${ }^{24}$ Wątek ten szeroko omówiony został przez Johna Felstinera - wkradam się w szczeliny pozostawione przez badacza i sięgam po nieomówione przezeń teksty.

25 J. Felstiner, op.cit., s. 191. 
się z twórcą Woroneskich zeszytów ${ }^{26}$ - by użyć słów Rosjanina „Gdzieś u bram Jerozolimy” ${ }^{27}$. Obaj mogli zapisać inne jego zdanie: „Żyjemy tu, nie czując pod stopami ziemi” ${ }^{28}$. Zapisywali je - z przerażającą konsekwencją - swoim losem.

Według Tadeusza Klimowicza „nauka rozstawania” ${ }^{29}$ znamionowała żydowski los Mandelsztama. Ale przecież także Celan odebrał tę lekcję. Obaj przyszli na świat w rodzinach zasymilowanych, niepraktykujących Żydów, poznali podstawy judaizmu, elementy tradycji judaistycznej przenikały do ich twórczości. Obaj skazani zostali na banicję, obaj pisali wiersze o pamięci. Akmeista urodzony w Warszawie w roku 1891, zmarły w 1938 w łagrze pod Władywostokiem, wspominał swojego ojca podobnie, jak Celan mógłby wspomnieć matkę:

Jak odrobina piżma napełnia wonią cały dom, tak najmniejszy wpływ judaizmu napełnia całe życie. $\mathrm{O}$, cóż za silny zapach! $3^{\circ}[. .$.$] .$ Nad ruinami Judei zaczynała się książkowa budowla, to byli Niemcy: Schiller, Goethe, Körner, stare wydania z Lipska [...]. To ojciec jako samouk z talmudycznych gąszczy przedzierał się do świata niemieckiego $^{3 \mathrm{I}}$.

Anna Glazova zauważa także inne koincydencje - i na poziomie biograficznym, i na płaszczyźnie praktyki literackiej: Mandelsztam krytykował nacisk kładziony na postęp technologiczny i stalinowską industrializację, Celan przeciwstawiał się w swoich wierszach nazistowskiej obsesji na punkcie maszyn. Obaj czuli się zobowiązani do podtrzymania pamięci o minionych pokoleniach, włączali się raczej do rozmowy z przeszłością, niż spoglądali w przyszłość ${ }^{2}$. Celan dedykował swój tom z $1963 \mathrm{r}$. pamięci kogoś skazanego na zagładę przed właściwą Zagładą. W wierszu Śluza odmawiał kadisz także za twórcę Woroneskich

${ }^{26}$ Zob. Ch. Ivanović, Das Gedicht im Geheimnis der Begegnung. Dichtung und Poetik Celans im Kontext seiner russischen Lektüren, M. Niemeyer, Tübingen 1996.

27 O. Mandelsztam, Nikomu ani stowa..., wybór, posłowie T. Klimowicz, tłum. zespół, Kraków 1998, s. 77.

${ }_{28}$ Ibidem, s. 183.

29 Ibidem, s. 253. Zob. też: R. Romaniuk, Radziecka ruletka. O Nadieżdzie Mandelsztam, w: idem, One. Nadieżda Mandelsztam, Anna Iwaszkiewiczowa, Zofia Totstojowa, Maria Kasprowiczowa, Warszawa 2005.

$3^{\circ} \mathrm{O}$. Mandelsztam, Nieograbiony i nierozgromiony. Wiersze $i$ szkice, thum., wybór, komentarze A. Pomorski, Warszawa 2011, s. 10.

${ }^{\text {I }}$ Ibidem, s. 11-12.

$3^{2}$ A. Glazova, Celan's Mandelstam, http://spintongues.vladivostok.com/ glazova35eng.htm, dostęp: 17 maja 2013. 
zeszytów, czynił go również adresatem wiersza Syberyjsko ${ }^{33}$, zaś obraz „czarnego słońca” z ostatniej strofy poniższego wiersza Mandelsztama z 1916 r. nietrudno skojarzyć z „czarnym mlekiem" w Fudześmierci:

[...] I nad matką zadzwoniły

Moich Żydów wszystkie dzwony.

I w kołysce się zbudziłem

Czarnym słońcem oślepiony ${ }^{34}$.

W przekładzie Celana wiersz ten brzmi:

Diese Nacht: nicht gutzumachen, bei euch: Licht, trotzdem.

Sonnen, schwarz, die sich entfachen

vor Jerusalem.

Sonnen, gelb: größeres Entsetzen schlaf, eiapopei.

Helles Judenhaus: sie setzen

Meine Mutter bei.

Sie die nicht mehr priesterlichen, gnad- und heilsberaubt, singen aus der Welt, im Lichte. eines Weibes Staub.

Judenstimmen, die nicht schwiegen, Mutter, wie es schallt.

Ich erwach in meiner Wiege.

sonnenschwarz umstrahlt ${ }^{35}$.

Mandelstamm to po niemiecku „pień migdałowy” ${ }^{6}$. Tom Die Niemandsrose tworzył Celan w okresie 1959-1963, a dwuletnie thumaczenie Mandelsztama zaczął w roku 1957. 17 kwietnia 1961 r. pisał Klaus Demus do poety: „Swoimi przekładami otwo-

33 L. Szaruga, Syberyjsko, w: Kartki Celana. Interpretacje, red. J. Roszak, Kraków - Budapeszt 2012, s. 305.

34 O. Mandelsztam, ${ }^{* * *}$ Ta nocpetna tez $i$ żalu, w: idem, Trzydzieści trzy wiersze. Przektady i komentarze Jarostawa Marka Rymkiewicza, Kraków 2003, s. 11.

35 O. Mandelstamm, Gedichte. Aus dem Russischen übertragen von Paul Celan, Frankfurt am Main 2004, s. 8.

${ }^{36}$ Migdał pojawi się jako atrybut między innymi w Mandorli, Nachmittag mit Zirkus und Zitadelle, Scbwarzerde, Eine Gauner- und Ganovenweise, In eins, Und mit dem Buch aus Tarussa, Mandelnde. 
rzyłeś nam, Paulu, Nani i mi, bramę do Rosjan - bramę, której już nie możemy stracić [...]; zaczynamy im wiele zawdzięczać” (CD, s. 384)37. Dwa lata wcześniej Demus notował do Celana o jego książce z przekładami Mandelsztama:

Z serca cieszymy się z Twojej wspaniałej nowej książki, to wielkie osiągnięcie. [...] Twój całkiem własny dar wolnego przekładu (słowo to nie brzmi najlepiej) jest dla mnie nadal nieprzenikniony, [...] nieustanne końce źródłowe, pączkowanie języka i prostota, poczucie czystości tonu. Nie można szukać „oryginału”, nie można szukać samego substratu. Wydaje się, że mówisz za niego, wydaje się, że stoi przy Tobie i [...] przekazał Ci język, abyś nim mówił. (Wiedeń, 12 października 1959; CD, s. 282-283)

Celan, tłumacząc Mandelsztama, tego właśnie pragnie: wyczuć pneumę rosyjskiego poety. W wierszu Es ist alles anders $\mathrm{z}$ tomu Die Niemandsrose (szkic tego utworu miał tytuł Elegia paryska) kreśli takie strofy:

Es ist alles anders, als du es dir denkst, als ich es mir denke, die Fahne weht noch, die kleinen Geheimnisse sind noch bei sich, sie werfen noch Schatten, davon

lebst du, leb ich, leben wir.

Die Silbermünze auf deiner Zunge schmilzt, sie schmeckt nach Morgen, nach Immer, ein Weg nach Rußland steigt dir ins Herz, die karelische Birke hat gewartet, der Name Ossip kommt auf dich zu, du erzählst ihm, was er schon weiß, er nimmt es, er nimmt es dir ab, mit Händen du löst ihm den Arm von der Schulter, den rechten, den linken, du heftest die deinen an ihre Stelle, mit Händen, mit Fingern, mit Linien,

- was abriß, wächst wieder zusammen da hast du sie, da nimm sie dir, da hast du alle beide, den Namen, den Namen, die Hand, die Hand, da nimm sie dir zum Unterpfand,

37 „Du hast uns, Paul, Nani und mir, mit Deinen Übertragungen ein Tor zu den Russen geöffnet - ein Tor, das wir nicht mehr missen können [...]; wir beginnen ihm schon vieles zu verdanken". 
er nimmt auch das, und du hast

wieder, was dein ist, was sein $\operatorname{war}^{8}{ }^{8}$,

Wszystko jest inne, niż myślisz, niż mi się myśli,

flaga wieje nadal,

małe tajemnice są jeszcze przy sobie,

rzucają jeszcze cienie, stąd

żyjesz, żyję, my żyjemy. (J.R.) ${ }^{39}$

Srebrnik topi się na twoim języku,

smakuje po jutrze, na zawsze, droga

do Rosji rośnie ci do serca,

karelska brzoza

była

czekała,

imię Osip zbliża się do ciebie, opowiadasz mu,

co już wie, bierze to, odbiera to od ciebie, dłońmi, odejmujesz mu rękę od ramienia, prawą, lewą, przypinasz swoje w ich miejsce, (M.T.) z rękami, palcami, liniami, (J.R.)

\section{- co oderwane, wyrasta na powrót na raz -}

Oto masz je, weź je sobie, oto masz podwójnie,

Imię, imię, ręka, ręka

Weź je sobie jako fant

On daje i to, a ty masz

Znów, co twoje jest, co było jego. (M.T.)

Celan odziewa powyższy utwór w imię „Osip”, a o wierszu „ubranym w imię” pisał Mandelsztam w thumaczonym przez autora Fugi śmierci liryku Znalazca podkowy. Owa „mała tajemnica” to zapewne i krople pamięci o Zagładzie, drążące podskórne korytarze, i skrzętnie ukrywane gesty destrukcyjne, wykonywane wobec Żydów ocalałych z Holocaustu. Wiąże się z nim także srebrnik - alegoria kamuflowanej zdrady, inicjująca drogę w głąb Rosji, drogę wrastającą w serce.

$3^{8}$ P. Celan, Die Gedichte. Kommentierte Gesamtausgabe in einem Band, red. B. Wiedemann, Frankfurt am Main 2005, s. 162.

39 Fragmenty oznaczone inicjałami M.T. pochodzą z przekładu Macieja Tomala (cyt. za: J. Felstiner, op.cit., s. 260-261), oznaczenie J.R. zamyka cząstki $\mathrm{w}$ thumaczeniu autorki artykułu. 


\section{Poczta butelkowa}

We wczesnym eseju Mandelsztam akcentował, że nie istnieje poezja bez dialogu i że gdy człowiek ma coś do powiedzenia, szuka słuchaczy ${ }^{40}$. Wierszowy zwrot do odbiorcy porównał on do poczty butelkowej ${ }^{41}$. Rosjanin pisał, iż ,poczta butelkowa”, tak samo jak wiersz, nie jest skierowana do nikogo określonego. Jednakże posiada adresata: tego, kto przez przypadek odkryje w piasku wyrzuconą przez morze butelkę. Dla wiersza (a miał na myśli utwór Jewgienija Boratyńskiego ${ }^{42}$ ) kimś podobnym jest „,czytelnik w potomności” 43 . Martina Broda stawia tezę, że Celan swoje myślenie o poezji zawdzięcza w dużej mierze temu właśnie esejowi młodego Mandelsztama, publikowanemu w „Apollonie”.

Paul Celan stale wędruje wzdłuż pamięci Zagłady, składowej historii, ale przede wszystkim własnego losu. Jego wyobraźnia wprawia tłumaczony tekst w ruch anabatyczny, lecz pamięć i doświadczenie najczęściej wiodą go ku katabazie. Tłumaczenie pozwala mu zachowywać własny język. W wielu jego wierszach, w których silnie uobecnia się autorskie „ja”, materiał (matière) cudzej poezji wżywa się w nowy wiersz, ożywia wargi. Poezja to wszelako „transfuzyjna krew dla pracy serca” ${ }^{44}$.

$4^{\circ}$ M. Broda, „An Niemand gerichtet”. Paul Celan als Leser von Mandelstamms „Gegenüber”, w: PaulCelan, red. W. Hamacher, W. Menninghaus, Frankfurt am Main 1988, s. 48: „ «Es gibt keine Lyrik ohne Dialog», heißt es im Mandelstams frühem Essay Über den Gespräcbspartner”.

${ }^{4}$ I Ibidem: „Diese Hinwendung zum Adressaten wird Mandelstam durch die Metapher der Flaschenpost anschaulich gemacht".

${ }^{42}$ O. Mandelstamm, Vom Gegenüber, tłum. D. Rodenwald, w: Paul Celan, s. 203.

43 Cyt. za: ibidem, s. 49: „Der Begriff [die Flaschenpost], genau wie Gedicht, ist an niemand Bestimmten gerichtet. Dennoch haben beide einen Adressaten: der Brief nämlich den, der die Flasche zufällig im Sand entdeckt, das Gedicht aber «den Leser in der Nachwelt»".

44 R. Krynicki, Poezja żywa, w: idem, Magnetyczny punkt. Wybrane wiersze i przektady, Warszawa 1996, s. 43: „Poezja - jest/ jak transfuzyjna krew dla pracy serca:/ choćby dawcy już dawno pomarli/ w nagłych wypadkach, to ich krew/ żyje - i cudze krwiobiegi spokrewnia, // i cudze ożywia wargi”. 


\section{JOANNA ROSZAK}

\section{Translator's ploughshare. Translation as a mode of internal immigration}

The theme of the article is translation as a mode of internal immigration. Paul Celan, who chose German as the language of his work, (it was the language of his mother and of murderers), found a sanctuary also as translator. In translator's profession, he found ways of distilling the German language, which never ceased to be his "internal landscape" in spite of the wound inflicted to the language by Nazism. Most of the discussion focuses on Celan's motivations when he translated Osip Mandelstam's poetry.

Keywords: internal immigration, German language and the Holocaust, translation, Jewish fate.

Joanna Roszak - adiunkt w Instytucie Slawistyki PAN. Autorka książek: Poludnik spotkania. Paul Celan w polskiej poezji powojennej, W cztery strony naraz. Portrety Tymoteusza Karpowicza, Synteza mowy Tymoteusza Karpowicza, Interior. Szkice. Współredaktorka tomów: Upominki dla Inki. Ksiega pamiatkowa dla prof. Aliny Brodzkiej, Konstelacje Ingeborg Bachmann, Pierwsza potowa Marcina. Szkice o twórczości Marcina Świetlickiego, Poznański przewodnik literacki, Powinowactwa Pessoi, Musical. Poszerzanie pola gatunku oraz redaktorka zbioru Kartki Celana. Interpretacje. Autorka tomów poetyckich Tintinnabuli, Lele, Wewe, Ladino.

e-mail: joannamroszak@gmail.com 